\title{
Article \\ Precipitation Behavior of O Phase during Continuous Cooling of Ti-22Al-25Nb Alloy
}

\author{
Dong $\mathrm{Li}^{1,2,3}$, Weidong Zeng ${ }^{1,2,3, *}$, Fan Zhang ${ }^{1,2,3}$, Jianwei $\mathrm{Xu}^{1,2,3}$, Xiong Ma ${ }^{4}$ and Xiaobo Liang ${ }^{4}$ \\ 1 State Key Laboratory of Solidification Processing, Northwestern Polytechnical University, Xi'an 710072, China; \\ 1d198712@163.com (D.L.); zhangfan344@163.com (F.Z.); jianwei_xu@nwpu.edu.cn (J.X.) \\ 2 Defense Technologies Innovation Center of Precision Forging and Ring Rolling, School of Materials Science \\ and Engineering, Northwestern Polytechnical University, Xi'an 710072, China \\ 3 Shaanxi Key Laboratory of High-Performance Precision Forming Technology and Equipment, \\ Northwestern Polytechnical University, Xi'an 710072, China \\ 4 High Temperature Materials Research Institute, Central Iron and Steel Research Institute, \\ Beijing 100081, China; maxiong1029@163.com (X.M.); liangxb257@163.com (X.L.) \\ * Correspondence: zengwd@nwpu.edu.cn; Tel.: +86-29-88494298
}

Citation: Li, D.; Zeng, W.; Zhang, F.; Xu, J.; Ma, X.; Liang, X. Precipitation Behavior of $\mathrm{O}$ Phase during Continuous Cooling of Ti-22Al-25Nb Alloy. Metals 2022, 12, 291. https:// doi.org/10.3390/met12020291

Academic Editor: Maciej Motyka

Received: 6 January 2022

Accepted: 3 February 2022

Published: 8 February 2022

Publisher's Note: MDPI stays neutral with regard to jurisdictional claims in published maps and institutional affiliations.

Copyright: (C) 2022 by the authors. Licensee MDPI, Basel, Switzerland. This article is an open access article distributed under the terms and conditions of the Creative Commons Attribution (CC BY) license (https:// creativecommons.org/licenses/by/ $4.0 /)$.

\begin{abstract}
The microstructure evolution and formation mechanism of the $\mathrm{O}$ phase in a Ti-22Al- $25 \mathrm{Nb}$ (at.\%) orthorhombic alloy resulting from different cooling rates were investigated. The results show that the morphology of the precipitated $O$ phase is significantly affected by the cooling rate. As the cooling rate decreases, the floccular $\mathrm{O}$, composed of many fine acicular $\mathrm{O}$ phases, gradually grows into the lamellar $\mathrm{O}$ phase. When the alloy is cooled from the $\mathrm{B} 2$ phase region, the grain boundary $\mathrm{O}$ $\left(\mathrm{O}_{\mathrm{GB}}\right)$ preferentially nucleates at the triple junctions and grain boundaries and forms the flat and the zig-zag $\mathrm{O}_{\mathrm{GB}}$ according to different cooling rates. The $\mathrm{O}_{\mathrm{GB}}$ consists of separated, flat $\mathrm{O}_{\mathrm{GB}}$ parts and unconnected, zig-zag $\mathrm{O}_{\mathrm{GB}}$ composed of multiple short, separated, flat $\mathrm{O}_{\mathrm{GB}}$ at a higher cooling rate. The zig-zag $\mathrm{O}_{\mathrm{GB}}$ presents a connected state due to the sufficient diffusion time at a lower cooling rate. When the alloy is cooled from the $\left(\mathrm{B} 2+\alpha_{2}\right)$ phase region, the increase of the phase boundary provides favorable conditions for the nucleation of the $\mathrm{O}$ phase due to the presence of $\alpha_{2}$ particles. The precipitated rim $O$ phase appears on the periphery of the $\alpha_{2}$ particles at lower cooling rates. The analysis indicates that the Widmanstätten intragranular $\mathrm{O}\left(\mathrm{O}_{\mathrm{WI}}\right)$ precipitated directly from the $\mathrm{B} 2$ phase maintains the plane relation with the parent $\mathrm{B} 2$ phase, and the Widmanstätten grain boundary $\mathrm{O}\left(\mathrm{O}_{\mathrm{WGB}}\right)$ holds the specific orientation relationship with one of the two adjacent $\mathrm{B} 2$ grains. The $\mathrm{O}_{\mathrm{GB}}$ keeps the specific orientation relationship with one of the B2 grains as much as possible. When it cannot maintain the specific orientation relationship with one of the $\mathrm{B} 2$ grains, the $\mathrm{O}_{\mathrm{GB}}$ maintains a near-orientation relationship with B2 grains on both sides to reduce the nucleation activation energy. Moreover, there can be more than one nucleation site for the $\mathrm{O}$ phase on a single $\mathrm{B} 2$ grain boundary to form the $\mathrm{O}_{\mathrm{GB}}$. The rim $\mathrm{O}$ phase formed through a decomposition reaction of $\alpha_{2} \rightarrow \alpha_{2}$ (Nb-lean) $+\mathrm{O}$ (Nb-rich) is controlled by a diffusional mechanism and maintains a specific orientation relationship, i.e., $\{001\} \mathrm{O} / /\{0001\} \alpha_{2}$ and $<110>\mathrm{O} / /<11 \overline{2} 0>\alpha_{2}$, with the parent $\alpha_{2}$ particles.
\end{abstract}

Keywords: Ti-22Al-25Nb alloy; cooling rate; microstructure evolution; $\mathrm{O}$ phase formation; orientation relationship

\section{Introduction}

With the development of aerospace technology, more stringent requirements are being imposed on the high-temperature service performance of aeroengine materials. The orthorhombic $\mathrm{Ti}_{2} \mathrm{AlNb}$-based alloys (titanium aluminides containing the $\mathrm{O}$ phase), discovered in the late 1980s by Banerjee [1], have received considerable attention and interest as potential advanced aerospace and elevated-temperature structural materials due to their low density, high specific strength, good creep resistance and elevated temperature strength [2-4]. Ti-22Al-25Nb (at.\%) alloy, as one of the typical second-generation 
orthorhombic $\mathrm{Ti}_{2} \mathrm{AlNb}$-based alloys, has a superior balance combination of strength, room temperature ductility and fracture toughness [5,6]. It can be used for long periods of service at $650{ }^{\circ} \mathrm{C}$ to $750{ }^{\circ} \mathrm{C}$ or for short periods of service at higher temperatures. Therefore, many studies related to the Ti-22Al-25Nb alloy, such as studies of its phase transformation, microstructure evolution and the relationship between microstructure and mechanical properties, have been conducted by various researchers [7-9].

As a Ti-Al-Nb ternary alloy, the Ti-22Al-25Nb alloy mainly contains three different phases: the B2 phase as an ordered, body-centered cubic phase; the $\alpha_{2}$ phase as a hexagonal, close-packed (base on $\mathrm{Ti}_{3} \mathrm{Al}$ ) phase; and the $\mathrm{O}$ phase as an orthorhombic (based on $\mathrm{Ti}_{2} \mathrm{AlNb}$ ) phase [10]. Due to the diversity of microstructures and the complexity of phase transformation, the microstructure and mechanical properties of the orthorhombic alloys are very sensitive to heat treatment. Boehlert [11] proposed that the ordered fully B2 microstructure exhibited room temperature strength up to $672 \mathrm{MPa}$ and low elongations ( $\leq 0.6 \mathrm{pct}$ ), and the ordered fully $\mathrm{O}$ (orthorhombic phase) microstructure exhibited intermediate strength ( $\leq 704 \mathrm{MPa}$ ) and $\varepsilon_{f}(\leq 1 \mathrm{pct})$. It was also found that fine $\mathrm{O}$ lamellae precipitated during aging provided significant strengthening for $\mathrm{Ti}-12 \mathrm{Al}-38 \mathrm{Nb}$, and the $(\mathrm{O}+\mathrm{B} 2)$ microstructure exhibited better tensile property with strength up to $1125 \mathrm{MPa}$ and large elongations ( $\geq 12$ pct). Zheng et al. [12] investigated the effect of three lamellar $\mathrm{O}$ of different sizes on tensile properties and found that fine acicular $\mathrm{O}$ precipitated during aging treatment improves the tensile strength (1057 MPa) in Ti-22Al-25Nb alloy. Wang et al. $[13,14]$ investigated the mechanical properties of designed bimodal lamellar $\mathrm{O}+\mathrm{B} 2$ microstructure, equiaxed $\mathrm{O} / \alpha_{2}+\mathrm{B} 2$ microstructure and duplex microstructure. They reported tensile strengths of $1066 \mathrm{MPa}-1172 \mathrm{MPa}, 1050 \mathrm{MPa}$ and $1111 \mathrm{MPa}$ for lamellar microstructure, equiaxed microstructure and duplex microstructure, respectively. The morphology and formation mechanism of the $\mathrm{O}$ phase has always been an issue of concern to the scientific community. Previous investigations revealed that there are three possible transformation paths to form the O phase: (I) $\alpha_{2} \rightarrow \mathrm{O}$, (II) B2 $\rightarrow \mathrm{O}$ and (III) $\alpha_{2}+\mathrm{B} 2 \rightarrow \mathrm{O}$. For the first path, Muraleedhran et al. [15] investigated the $\alpha_{2}$-to-O transformation in Ti-28.5Al-13Nb (at.\%) and found the transformation of $\alpha_{2} \rightarrow \mathrm{O}$ is accomplished by a lattice distortion and a small composition change. Wu et al. [16] found the formation of the $\mathrm{O}$ phase is due to the niobium diffusion of the $\alpha_{2}$ phase, which separates into niobium-lean and niobium-rich regions in Ti-24Al-14Nb-3V-0.5Mo (at.\%). Wang et al. [17] investigated the formation mechanism of the fine, plate-like $\mathrm{O}$ phases within $\alpha_{2}$-phases and the tensile behavior of an isothermally forged Ti-22Al-25Nb (at.\%) orthorhombic alloy at $1040{ }^{\circ} \mathrm{C}$ during heat treatment, and they found the equiaxed $\alpha_{2}$-phase was not stable and decomposed into $\mathrm{O}+\alpha_{2}$ phases. For the second path, Sadi et al. [18] found that the unit cell of the $O$ phase can be directly derived from that of the B2 phase by a systematic TEM investigation in Ti-25Al-25Nb, Ti-22Al-28Nb and Ti-22Al-22Nb. Bendersky et al. $[19,20]$ predicted there should be several possible decomposition paths of the $\beta$ phase with the A2 (b.c.c.) symmetry. They lead to the same $\mathrm{O}$ phase but with different types and hierarchy of domain interfaces at room temperature. Muraleedharan et al. [21] found that the transformation of $\mathrm{B} 2 \rightarrow \mathrm{O}$ takes place in the temperature range at which the orthorhombic phase is stable and does not give rise to a change in composition; for this reason, the author concluded a massive transformation. Wei et al. [22] found that under the condition of B2 slow-cooling aging, there are two kinds of nucleation mechanisms of the $\mathrm{O}$ phase from the $\mathrm{B} 2$ grain boundary, i.e., sympathetic nucleation and interface instability nucleation. For the third path, according to research by Muraleedharan and coworkers [23], the $\mathrm{O}$ phase can be formed at the $\mathrm{B} 2 / \alpha_{2}$ interface by the eutectoid reaction in a Ti- $24 \mathrm{Al}-15 \mathrm{Nb}$ alloy. As mentioned above, the properties of the $\mathrm{Ti}_{2} \mathrm{AlNb}$-based alloy are extremely sensitive to changes in the microstructure, which mainly depend on the thermomechanical treatment process parameters, especially the cooling rate during heat treatment. Therefore, it is essential to investigate the microstructure evolution of Ti-22Al-25Nb under different cooling rates during heat treatment. However, for a $\mathrm{Ti}-22 \mathrm{Al}-25 \mathrm{Nb}$ alloy, there is seldom systemic investigation that focuses on microstructure evolution and phase transformation during a continuous cooling process [24]. 
This paper reports research on microstructure evolution and the formation of the $\mathrm{O}$ phase of a Ti-22Al-25Nb (at.\%) alloy cooled from different phase regions through accurate controlling of the cooling rate. The primary objective of this work is to investigate the formation mechanism of the precipitated $\mathrm{O}$ from the analysis of the morphological characteristics and orientation relationship with the parent phase. This information will be beneficial to obtain a better microstructure in practical production.

\section{Materials and Experimental Procedure}

The alloy with a nominal composition of Ti-22Al-25Nb (at.\%) was provided by Central Iron and Steel Research Institute (CISRI, Beijing, China) as a bar, and its chemical composition was determined by inductively coupled plasma atomic emission spectrometry (ICP-AES) as shown in Table 1 . The bar was isothermally forged to a pancake with a diameter of $350 \mathrm{~mm}$ and a height of $40 \mathrm{~mm}$ at $960{ }^{\circ} \mathrm{C}(\mathrm{O}+\mathrm{B} 2$ phase regions). The microstructure of the alloy after isothermal forging is shown in Figure 1. The B2 transus temperature of the Ti-22Al-25Nb alloy was $1060^{\circ} \mathrm{C}$ as determined by metallographic observations. It can be seen from the light microscopy (LM) image (Figure 1a) that the microstructure of the alloy after isothermal forging consists of the equiaxed $\alpha_{2} / \mathrm{O}$ particles, lamellar $\mathrm{O}$ and B2 matrix. The distribution of the equiaxed $\alpha_{2} / \mathrm{O}$ particles is random and homogeneous. Figure $1 \mathrm{~b}$ presents the scanning electron microscope image of the as-received material. The dark regions represent $\alpha_{2}$ phases, the gray regions represent $O$ phases and the light regions represent $\mathrm{B} 2$ phases in backscattered electron (BSE) mode. It can be identified that the equiaxed $\alpha_{2} / O$ particle consists of $\alpha_{2}$ particles and rim $O$ from different colors. Continuous cooling specimens were cut from the pancake using a low-speed wire electrical discharge machine (DK7732HB, Posittec Equipment, Suzhou, China). The surface of each specimen was cut by lathe with a final dimension of $\Phi 4 \mathrm{~mm} \times 10 \mathrm{~mm}$. A series of heat treatments were conducted in Bähr DIL805 A/D equipment (TA Instruments, New Castle, DE, USA)., which is a high-precision differential dilatometer. In the following experiments, the specimens were heated to $1100{ }^{\circ} \mathrm{C}$ and $1020^{\circ} \mathrm{C}$ at a rate of $50{ }^{\circ} \mathrm{C} / \mathrm{s}$ for $20 \mathrm{~min}$ and then cooled to room temperature at different rates $\left(0.1^{\circ} \mathrm{C} / \mathrm{s}, 0.4{ }^{\circ} \mathrm{C} / \mathrm{s}, 1^{\circ} \mathrm{C} / \mathrm{s}, 4{ }^{\circ} \mathrm{C} / \mathrm{s}\right.$ and $10{ }^{\circ} \mathrm{C} / \mathrm{s}$ ). In order to better observe the changes in microstructure evolution and phase transformation, the specimens were sectioned in half at the location of the middle length, prepared through conventional metallographic techniques, i.e., the specimens were first coarsely ground on a metallographic pre-grinder with 80\# metallographic sandpaper, then finely ground with 1000\# metallographic sandpaper and finally polished with silica polishing agent (the dimension of the silica polishing agent is 0.05 microns) to reach the mirror surface. They were then etched with a corrosive of $11 \% \mathrm{HF}, 33 \% \mathrm{HNO}_{3}$ and $56 \%$ $\mathrm{H}_{2} \mathrm{O}$ in volume fraction. The microstructural evolution and phase morphologies of the alloy were examined using light microscopy (LM, OLYMPUS/PMG3, Olympus Corporation, Tokyo, Japan) and scanning electron microscope (SEM, ZEISS SUPRA55, Carl Zeiss AG, Jena, Germany) with backscattered electron (BSE) mode. The phase identification of the Ti-22Al-25Nb alloy under different cooling rates was made by $\mathrm{X}$-ray diffraction (XRD, PANalytical X'Pert PRO, PANalytical B. V, Almelo, Netherlands) analysis through filtered $\mathrm{Cu}-\mathrm{K} \alpha$ radiation. The diffraction angle $(2 \theta)$ ranges from $30^{\circ}$ to $80^{\circ}$. The $\mathrm{XRD}$ data were analyzed using Jade 6.0 software (Materials Data, Newtown Square, PA, USA). The orientation analysis was carried out by electron backscattered diffraction (EBSD) equipment installed on the Helios NanoLab G3 dual-beam electron microscope (FEI Company, Hillsboro, OR, USA). The specimens for EBSD testing were prepared via electrolytic polishing without etching. The components of the electrolyte were $10 \%$ perchloric acid, 35\% n-butyl alcohol and 55\% methanol in volume fraction. The electrolytic polishing process lasted for $40 \mathrm{sec}$ at a voltage of $40 \mathrm{~V}$ and a current of under $1 \mathrm{~A}$ at $15^{\circ} \mathrm{C}$. During the EBSD testing, the samples were placed on a $70^{\circ}$ sample stage. The step size, testing voltage and current of the EBSD analysis were $0.1 \mu \mathrm{m}, 20 \mathrm{kV}$ and $6.4 \mathrm{nA}$, respectively. The micrographs were analyzed using a quantitative metallographic image analysis system (Image-Pro Plus 6 software, Media Cybernetics, Rockville, MD, USA) to measure the size of the precipitates. 
The microhardness testing was performed at 5 different locations on each specimen with an HY-1000A microhardness tester. The loading weight and holding time for each testing location was $200 \mathrm{~g}$ and $15 \mathrm{~s}$.

Table 1. Chemical composition of Ti-22Al-25Nb alloy.

\begin{tabular}{cccccc}
\hline $\begin{array}{c}\text { Al } \\
(\mathbf{a t .} \% \\
(\mathbf{w t .} \%)\end{array}$ & $\begin{array}{c}\mathbf{N b} \\
(\mathbf{a t .} \% \\
(\mathbf{w t .} \%)\end{array}$ & $\begin{array}{c}\mathbf{O} \\
\text { (ppm) }\end{array}$ & $\begin{array}{c}\mathbf{N} \\
(\mathbf{p p m})\end{array}$ & $\begin{array}{c}\mathbf{H} \\
(\mathbf{p p m})\end{array}$ & $\mathbf{T i}$ \\
\hline 22.3 & 25.7 & 430 & 52 & 9 & Bal. \\
\hline
\end{tabular}

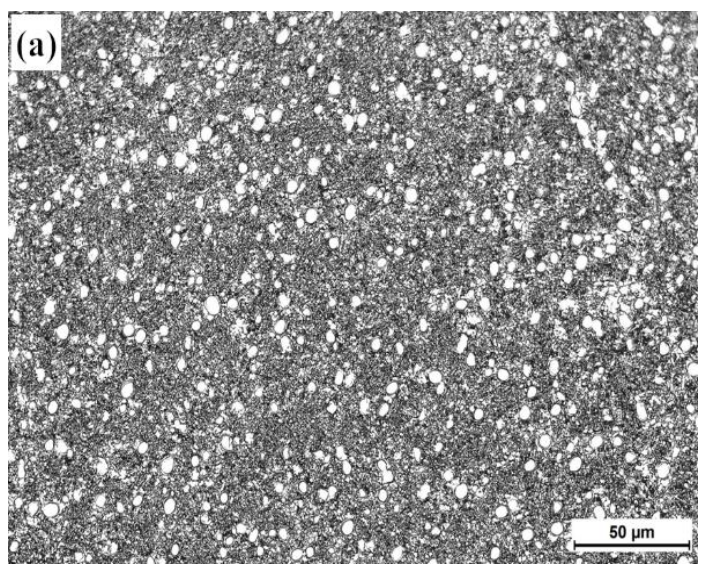

(a)

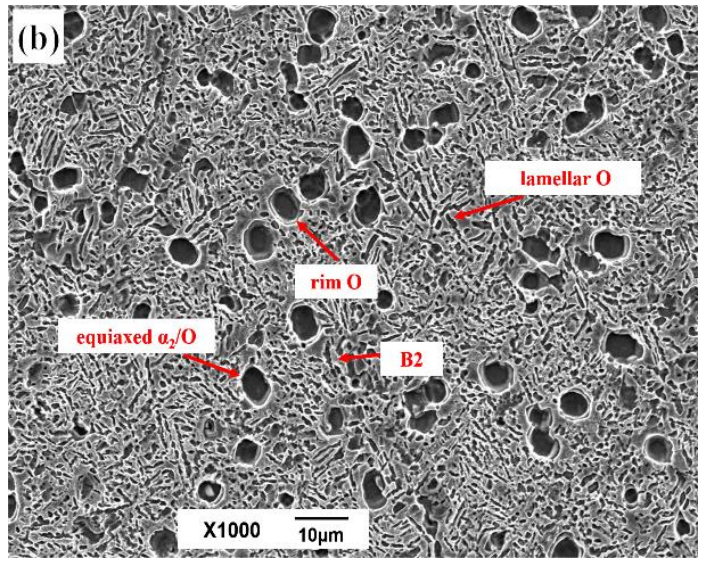

(b)

Figure 1. Microstructure of the as-received Ti-22Al-25Nb alloy: (a) LM, (b) SEM.

\section{Results and Discussion}

3.1. The Effect of Cooling Rate on the Microstructure of Precipitated O Phase

3.1.1. The Effect of Cooling Rate on Microstructure following Heating at B2 Region

The light microscopic observations of the Ti-22Al-25Nb alloy cooled at different rates after solution treatment at $1100{ }^{\circ} \mathrm{C}$ are shown in Figure 2. As seen from Figure 2, the microstructure morphology has gone through a series of significant changes, which revealed that microstructural evolution is greatly affected by the cooling rates. The specimens cooled at $10{ }^{\circ} \mathrm{C} / \mathrm{s}$ and $4{ }^{\circ} \mathrm{C} / \mathrm{s}$ (Figure $2 \mathrm{a}, \mathrm{b}$ ) show the retention of the high-temperature $\beta / \mathrm{B} 2$ phase, in which the $\beta$ phase is a disordered bcc phase and the B2 phase is an ordered cubic phase. Hagiwara et al. [25] found that the high-temperature single phase of a Ti-22Al-27Nb alloy at homogenization temperature $\left(1200{ }^{\circ} \mathrm{C}\right)$ already turned to an ordered state, and this state can be maintained by quench. Thus, we considered the hightemperature phase retained by rapid cooling in our work as an ordered B2 phase. Based on Ref. [8], the types of phases were determined as shown in Figure $2 \mathrm{f}$. The XRD pattern and metallographic images show that no second phase precipitated at the grain boundary or interior of the B2 phase. Huang et al. [24] discovered a similar phenomenon in a Ti$22 \mathrm{Al}-25 \mathrm{Nb}$ alloy subjected to solution treated at $1100{ }^{\circ} \mathrm{C}$ followed by water quenching. They proposed that rapid cooling suppresses the transformation related to long-range diffusion. According to the Ti-22Al-xNb alloy diagram depicted by Raghavan [26], the window for phase transformation to form a new $\alpha_{2}$ phase was narrow, and higher cooling rates resulted in a short time for element diffusion. When the cooling rate decreases to $1{ }^{\circ} \mathrm{C} / \mathrm{s}$ and $0.4{ }^{\circ} \mathrm{C} / \mathrm{s}$ (Figure $2 \mathrm{c}, \mathrm{d}$ ), it can be seen from the XRD pattern that the precipitates are $\mathrm{O}$ phase. There are two main characteristics of $\mathrm{O}$ phase precipitation: (1) fine acicular $\mathrm{O}$ phase non-uniformly precipitated directly from the B2 matrix and (2) the B2 grain boundary was decorated with the grain boundary $\mathrm{O}\left(\mathrm{O}_{\mathrm{GB}}\right)$ and the Widmanstätten grain boundary $\mathrm{O}\left(\mathrm{O}_{\mathrm{WGB}}\right)$ precipitated along the grain boundary. The fine acicular $\mathrm{O}$ phase gathered into 
many clusters, which is called the floccular $\mathrm{O}$ in the present work. The microstructure is different from that of the Ti-24Al-15Nb alloy with a similar cooling rate $\left(0.7^{\circ} \mathrm{C} / \mathrm{s}\right)$, which exhibits a fully lath microstructure [27]. This is mainly due to the difference in niobium content. The high niobium content decelerated diffusion processes in the Ti-22Al-25Nb alloy and led to sluggish phase transformations [28]. The dispersed floccular structure of the $\mathrm{O}$ phase is related to the diffusion processes of the $\mathrm{B} 2 \rightarrow \mathrm{O}$ transformation in a wide temperature range during the cooling process [29]. At a cooling rate of $0.1{ }^{\circ} \mathrm{C} / \mathrm{s}$ (Figure 2e), the size of the acicular $\mathrm{O}$ phase changed greatly; both the thickness and the length increased to lamellar $\mathrm{O}$ and, a typical Widmanstätten structure appeared in the B2 grain. Kazantseva et al. [30] determined the temperature boundaries of phase transformations in Ti-22Al-26.6Nb, Ti-23.5Al-21Nb and Ti-24.6Al-22Nb, respectively. They found that as the aluminum content increases, the temperature range of existence of the orthorhombic $\mathrm{O}$ phase extends. Therefore, the formation of these microstructure was due to the fact that the $\mathrm{O}$ phase has a large temperature range of formation and sufficient time for nucleation and growth at a lower cooling rate for the Ti-22Al-25Nb alloy. In addition, the decrease in the cooling rate can improve the diffusion process of alloying elements, especially the diffusion of $\mathrm{Nb}$.

(a)

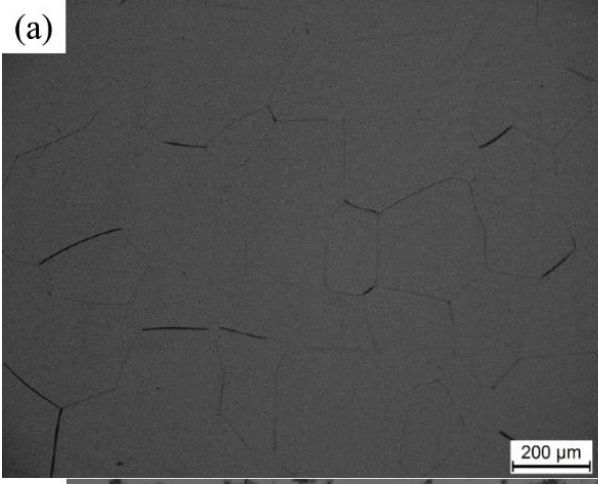

(c)

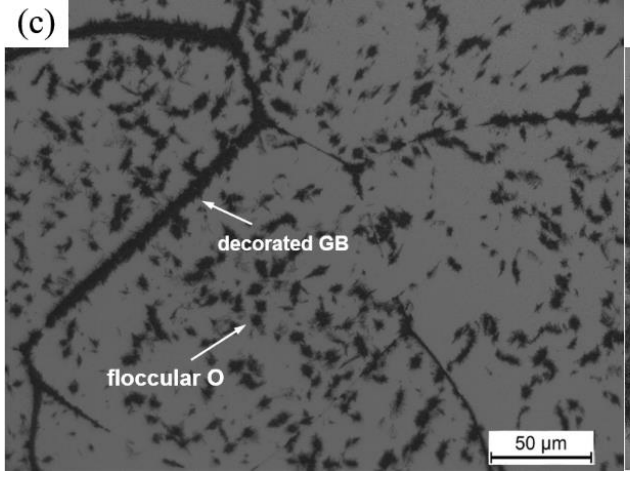

(e)

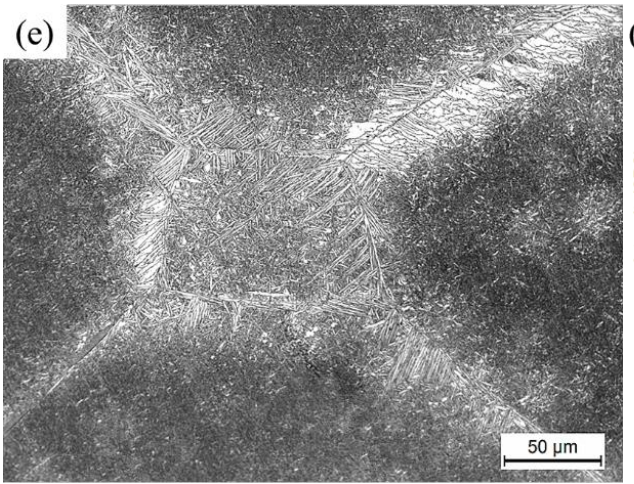

(b)
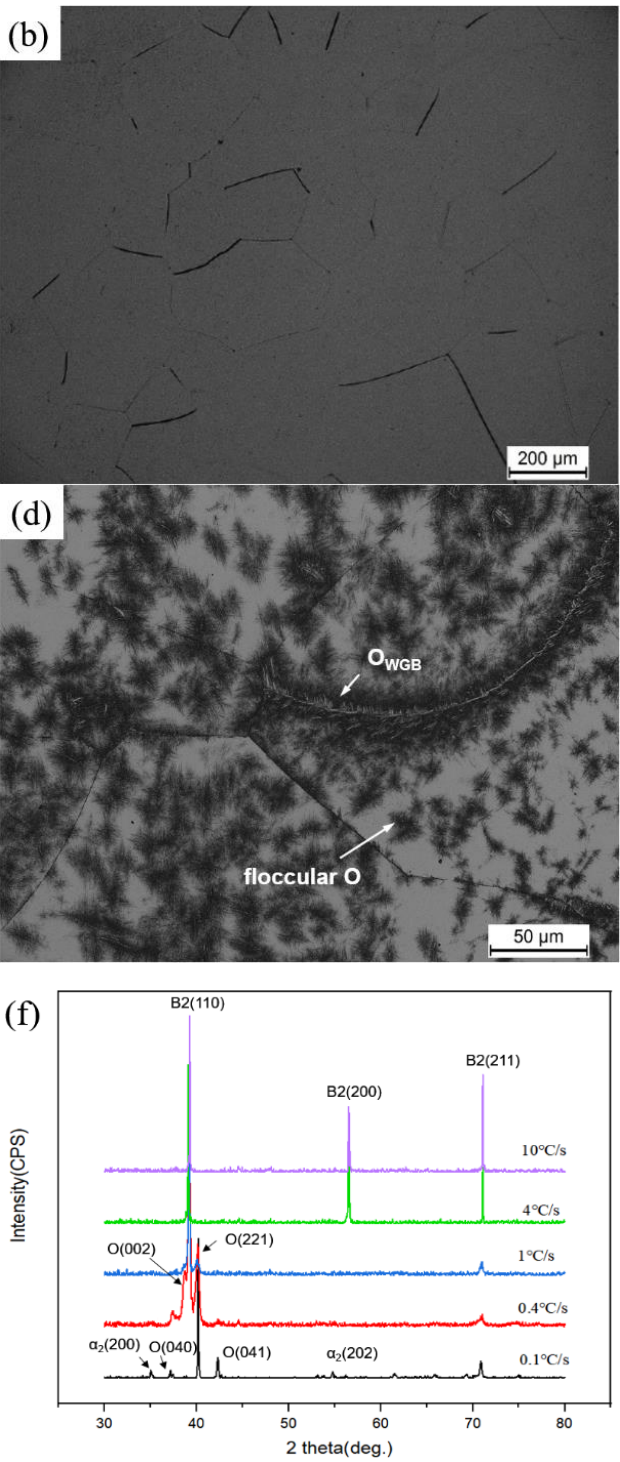

Figure 2. Light microscope images and phase identification of Ti-22Al-25Nb alloy cooled at different rates from $1100{ }^{\circ} \mathrm{C}$ : (a) $10{ }^{\circ} \mathrm{C} / \mathrm{s},\left(\right.$ b) $4{ }^{\circ} \mathrm{C} / \mathrm{s},\left(\right.$ c) $1{ }^{\circ} \mathrm{C} / \mathrm{s},\left(\right.$ d) $0.4{ }^{\circ} \mathrm{C} / \mathrm{s},\left(\right.$ e) $0.1{ }^{\circ} \mathrm{C} / \mathrm{s}$, (f) XRD pattern. 
To further confirm the characteristics of the precipitates on the B2 grain boundary at lower cooling rates following heat treatment at $1100^{\circ} \mathrm{C}, \mathrm{SEM}$ with BSE mode observations are shown in Figure 3. At a cooling rate of $1^{\circ} \mathrm{C} / \mathrm{s}$ (Figure 3a), part of the $\mathrm{B} 2$ grain boundary was decorated with flat $\mathrm{O}_{\mathrm{GB}}$ and zig-zag $\mathrm{O}_{\mathrm{GB}}$, which appeared around the triple junctions (TJs) preferentially. The grain boundary, especially the TJs, as a typical crystal defect, was conductive to nucleation and the growth of $\mathrm{O}_{\mathrm{GB}}$ due to the high defect energy. The flat $\mathrm{O}_{\mathrm{GB}}$ precipitated partially along the B2 grain boundary and formed two separated, flat $\mathrm{O}_{\mathrm{GB}}$ parts as shown in Figure $3 a$. Figure $3 \mathrm{~b}$ is a partial, enlarged view of Figure $3 \mathrm{a}$. As seen from Figure $3 b$, the zig-zag $\mathrm{O}_{\mathrm{GB}}$ was composed of multiple short, separated, flat $\mathrm{O}_{\mathrm{GB}}$ in an unconnected state. It is noteworthy that the growth direction of these short, separated, flat $\mathrm{O}_{\mathrm{GB}}$ is not consistent with the direction of the $\mathrm{B} 2$ grain boundary extension line (white dotted line). Sun et al. [31] observed the flat and zig-zag morphology of $\alpha_{\mathrm{GB}}$ in a TA 15 alloy, and proposed that the flat and zig-zag $\alpha_{\mathrm{GB}}$ had a competitive growth relationship. As the cooling rate decreased to $0.4{ }^{\circ} \mathrm{C} / \mathrm{s}$ (Figure $3 \mathrm{c}$ ), the flat and zig-zag $\mathrm{O}_{\mathrm{GB}}$ decorated one $\mathrm{B} 2$ grain boundary simultaneously, forming a mixed $\mathrm{O}_{\mathrm{GB}}$. This indicated that the $\mathrm{O}_{\mathrm{GB}}$ could nucleate separately and simultaneously on one B2 grain boundary. Moreover, there is a competitive relationship between the growth of flat and zig-zag $\mathrm{O}_{\mathrm{GB}}$. The $\mathrm{O}_{\mathrm{WGB}}$ were found near the zig-zag $\mathrm{O}_{\mathrm{GB}}$. As the cooling rate decreased further (Figure 3d), the B2 grain boundary was decorated with a different morphology of $\mathrm{O}_{\mathrm{GB}}$, and the zig-zag $\mathrm{O}_{\mathrm{GB}}$ presented a connected state. This was mainly due to the lower cooling rate, which allowed the $\mathrm{O}_{\mathrm{GB}}$ to have sufficient time to nucleate, grow and form the flat or connected zig-zag $\mathrm{O}_{\mathrm{GB}}$ to decorate the entire $\mathrm{B} 2$ grain boundary [32]. Compared with the microstructure at higher cooling rates, more Widmanstätten grain boundary $\mathrm{O}\left(\mathrm{O}_{\mathrm{WGB}}\right)$ and Widmanstätten intragranular $\mathrm{O}\left(\mathrm{O}_{\mathrm{WI}}\right)$ appeared at a cooling rate of $0.1{ }^{\circ} \mathrm{C} / \mathrm{s}$. The similar characteristic, which was the growth direction of the zig-zag $\mathrm{O}_{\mathrm{GB}}$ deflected from the extension line of the $\mathrm{B} 2$ grain boundary, existed in unconnected, zig-zag $\mathrm{O}_{\mathrm{GB}}$ and connected zig-zag $\mathrm{O}_{\mathrm{GB}}$. As seen in Figure $3 c, d$, the $\mathrm{O}_{\mathrm{WGB}}$, which precipitated from the $\mathrm{O}_{\mathrm{GB}}$, grew to one of the two adjacent $\mathrm{B} 2$ grains. It was known that the $\mathrm{O}$ phase followed a certain variant selection (VS) in relation to the parent B2 phase as $\{001\} \mathrm{O} / /\{110\} \mathrm{B} 2$ and $<110>\mathrm{O} / /<111>\mathrm{B} 2$ [33]. The orientation relationship between the precipitated $\mathrm{O}$ and $\mathrm{B} 2$ matrix will be discussed in detail later.

\subsubsection{The Effect of Cooling Rate on Microstructure following Heating at $\left(\mathrm{B} 2+\alpha_{2}\right)$ Region}

Light microscope images of the Ti-22Al-25Nb alloy solution treated at $1020{ }^{\circ} \mathrm{C}$ for $20 \mathrm{~min}$ and cooled at different rates are shown in Figure 4 . When the specimen was cooled at a high rate $\left(10^{\circ} \mathrm{C} / \mathrm{s}\right.$ or $\left.4^{\circ} \mathrm{C} / \mathrm{s}\right)$ as shown in Figure $4 \mathrm{a}, \mathrm{b}$, the high-temperature $\mathrm{B} 2$ phase and $\alpha_{2}$ particles were retained in the alloy. According to Ref. [7], we determined the types of phases shown in Figure 4f. It can also be seen from the XRD pattern that the O phase does not exist at this time. The size of the particles is slightly smaller than the particles in the as-received $\mathrm{Ti}-22 \mathrm{Al}-25 \mathrm{Nb}$ alloy due to rim $\mathrm{O}$ dissolution of the initial $\alpha_{2} / \mathrm{O}$ particles after heating at the $\left(\mathrm{B} 2+\alpha_{2}\right)$ region. Compared with a high cooling rate following heat treatment at the B2 region, the B2 grain size was smaller when heated at the $\left(B 2+\alpha_{2}\right)$ region. This was mainly caused by the combination of a low heating temperature and the pinning effect of the $\alpha_{2}$ particle [34]. When the cooling rate was $1^{\circ} \mathrm{C} / \mathrm{s}$ (Figure $4 \mathrm{c}$ ), acicular $\mathrm{O}$ were precipitated from the B2 matrix, B2 grain boundaries and around $\alpha_{2}$ particles. Similar to cooling from $1100{ }^{\circ} \mathrm{C}$, these fine, needle-like $\mathrm{O}$ lamellae cluster together, forming a floccular microstructure. When cooled from the two-phase region, the increase of the phase boundary provides favorable conditions for the nucleation of the $\mathrm{O}$ phase due to the presence of $\alpha_{2}$ particles in the grains. As the cooling rate decreases to $0.4{ }^{\circ} \mathrm{C} / \mathrm{s}$ (Figure $4 \mathrm{~d}$ ), the volume fraction of the floccular $\mathrm{O}$ phase precipitated in the $\mathrm{B} 2$ grains and around the $\alpha_{2}$ particles increased, and it was observed that the diameter of the $\alpha_{2}$ particles decreased, as shown by the white arrows. As the cooling rate was deceased further (Figure 4e), the $\mathrm{O}_{\mathrm{WI}}$ and the $\mathrm{O}$ phase precipitated around the $\alpha_{2}$ particles were significantly coarsened, and the volume fraction of the $\alpha_{2}$ particles decreased. 

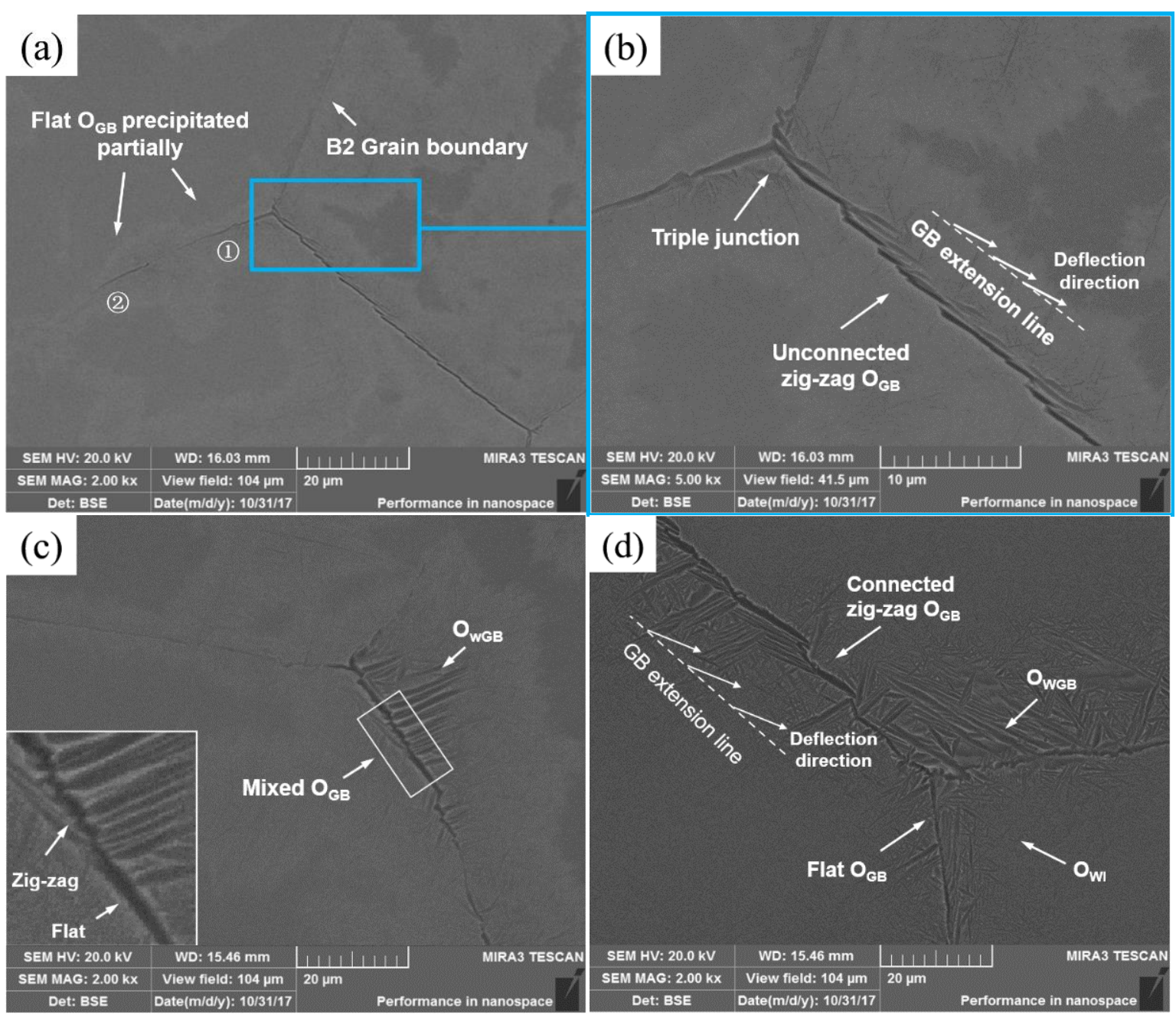

Figure 3. The morphology of Ti-22Al-25Nb alloy cooled at different rates from $1100{ }^{\circ} \mathrm{C}:(\mathbf{a}, \mathbf{b}) 1{ }^{\circ} \mathrm{C} / \mathrm{s}$, (c) $0.4^{\circ} \mathrm{C} / \mathrm{s},(\mathbf{d}) 0.1^{\circ} \mathrm{C} / \mathrm{s}$.

Typical scanning electron microscopy micrographs on microstructure changes after cooling from $1020^{\circ} \mathrm{C}$ at different rates are shown in Figure 5. It can be observed that at a relatively high cooling rate (Figure $5 \mathrm{a}$ ), there was no rim $\mathrm{O}$ phase around the $\alpha_{2}$ particles, and the surface of the equiaxed particles was relatively smooth. When cooled at $1{ }^{\circ} \mathrm{C} / \mathrm{s}$ (Figure 5b), a small amount of floccular O phase appeared in the B2 matrix and around the $\alpha_{2}$ particles. As the cooling rate decreased (Figure $5 \mathrm{c}$ ), a large number of floccular $\mathrm{O}$ phases appeared around the $\alpha_{2}$ particles, and rim $O$ phase appeared around a few $\alpha_{2}$ particles. With further decreases in the cooling rate (Figure $5 \mathrm{~d}$ ), rim $\mathrm{O}$ phase appeared around almost all $\alpha_{2}$ particles, and the $\alpha_{2}$ particles were no longer smooth. Meanwhile, it is observed that some $\alpha_{2}$ particles were being dissolved. A similar $\alpha_{2}$ decomposition phenomenon was discovered by Wang et al. [17], who found that $\alpha_{2}$ particles decomposed into the fine, plate-like $\mathrm{O}$ phase $+\alpha_{2}$ phase during aging treatment.

\subsection{O Phase Precipitation Mechanism}

3.2.1. O Phase Precipitation Mechanism from B2 Matrix

To investigate the relationship between the precipitated $\mathrm{O}$ phase and the parent $\mathrm{B} 2$ matrix, EBSD analysis of Ti-22Al-25Nb alloy cooled at $0.1{ }^{\circ} \mathrm{C} / \mathrm{s}$ from $1100{ }^{\circ} \mathrm{C}$ is shown in Figure 6. Figure $6 \mathrm{a}$ is the scanning electron microscope image of the EBSD analysis area. As seen from the inverse pole figure (IPF) of B2 phases in Figure 6b, there are three different crystallographic orientation B2 grains at the triple junctions. The morphology and orientation characteristics of the precipitated $\mathrm{O}$ phase in different $\mathrm{B} 2$ grains has significant 
changes, as shown in Figure 6c. On the \#1 B2 grain boundary, lamellar $\mathrm{O}_{\text {WGB }}$ phase precipitated along grain boundaries and grew into \#1 B2 grain, (mark by the red rectangle). In the \#2 B2 grain, the clustered lamellar OWGB $_{\text {phase with different crystallographic }}$ orientations formed visual parallel colony structures, as marked by the black arrows. It is worth noting that on the grain boundary between the \#1 B2 grain and \#2 B2 grain (marked by the black rectangle), the precipitated $\mathrm{O}_{\mathrm{WGB}}$ grew into different B2 grains, \#1 B2 grain and \#2 B2 grain, respectively. No colony structure observed on the \#3 B2 grain boundary and fine acicular $\mathrm{O}$ phase in the B2 grain precipitated directly from the parent B2 matrix, and there was no obvious visual orientation.
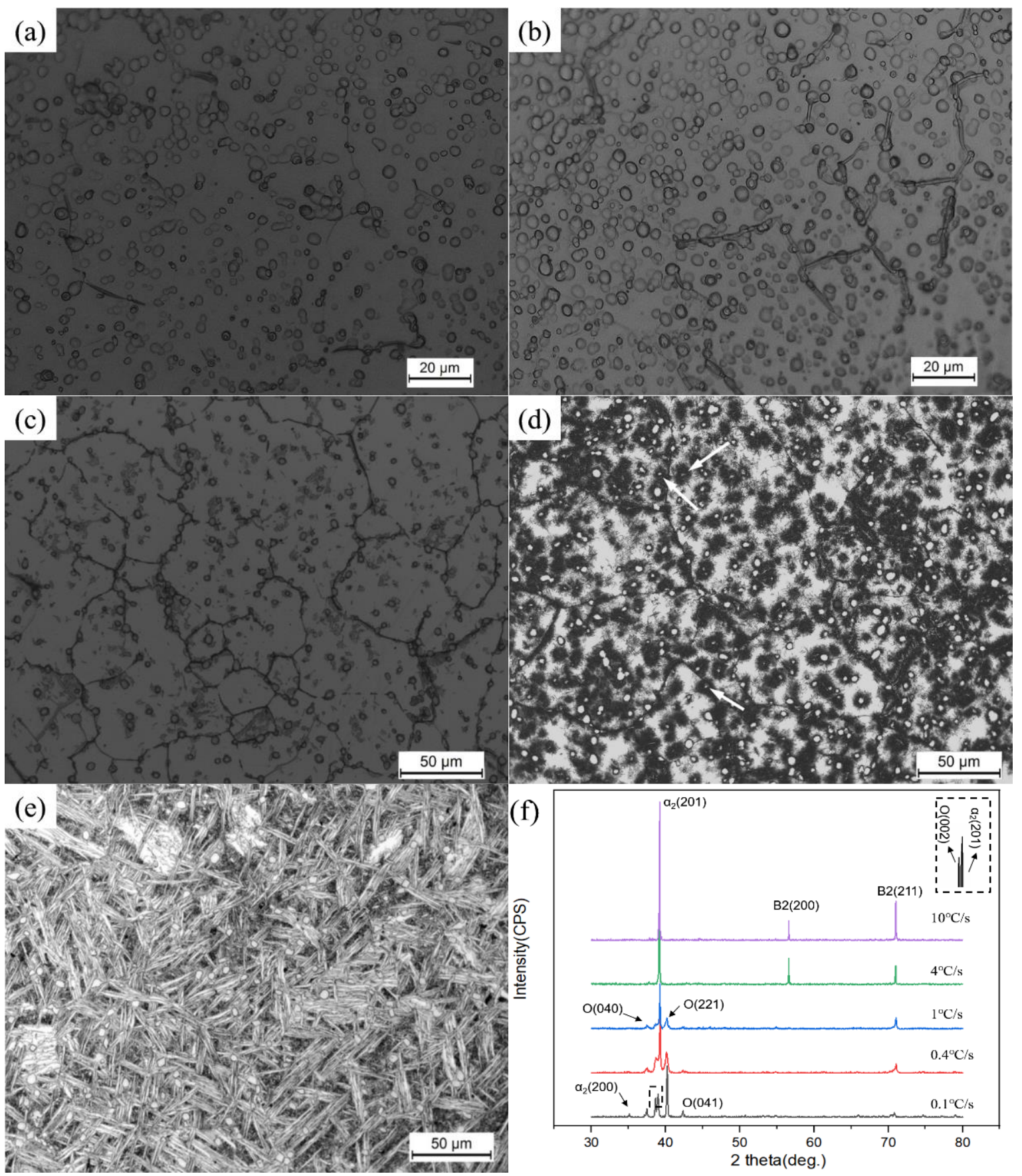

Figure 4. Light microscope images and phase identification of Ti-22Al-25Nb alloy cooled at different rates from $1020^{\circ} \mathrm{C}$ : (a) $10{ }^{\circ} \mathrm{C} / \mathrm{s},\left(\right.$ b) $4{ }^{\circ} \mathrm{C} / \mathrm{s},(\mathbf{c}) 1^{\circ} \mathrm{C} / \mathrm{s}$, (d) $0.4{ }^{\circ} \mathrm{C} / \mathrm{s},(\mathbf{e}) 0.1^{\circ} \mathrm{C} / \mathrm{s},(\mathbf{f}) \mathrm{XRD}$ pattern. 

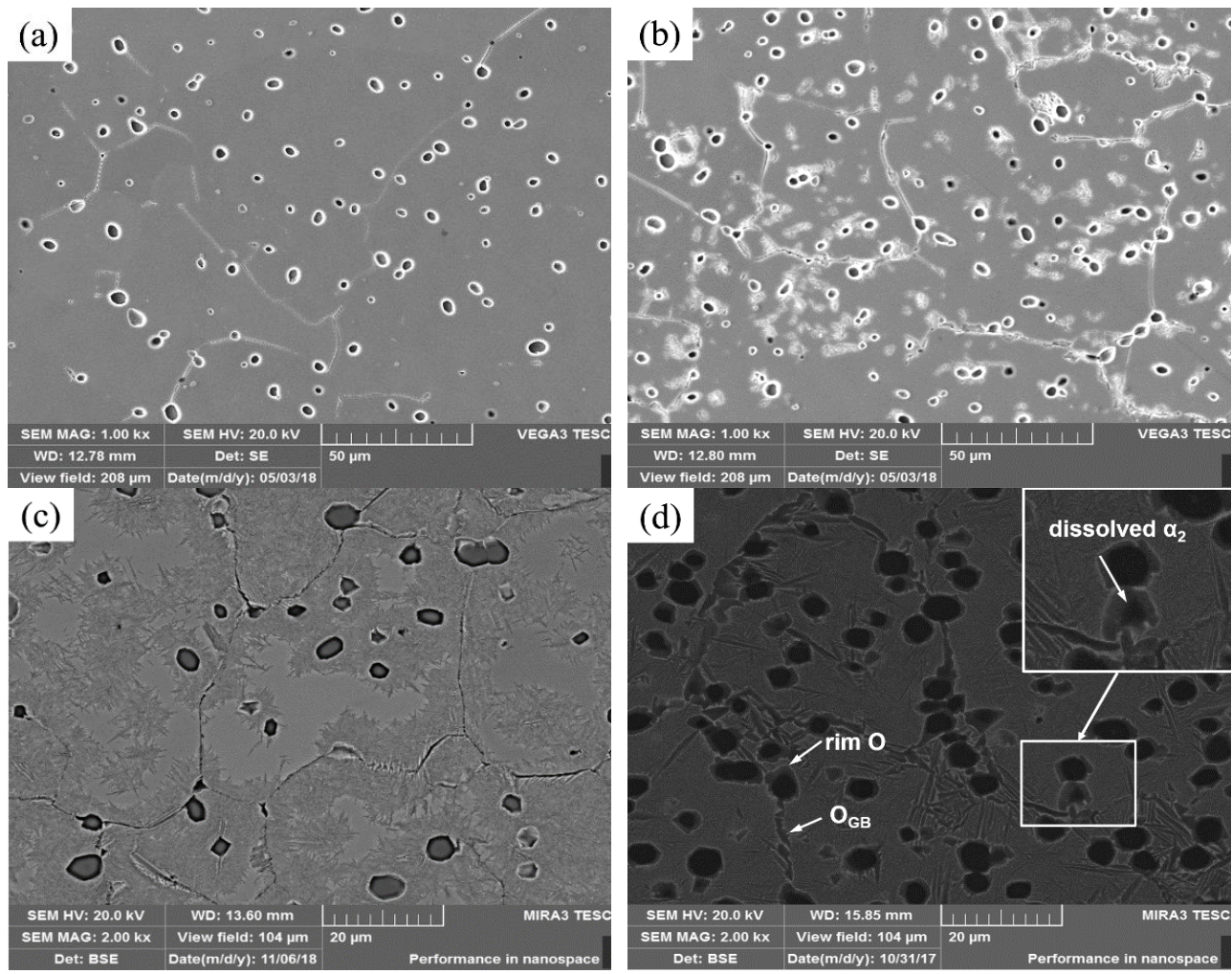

Figure 5. Scanning electron micrographs of Ti-22Al-25Nb alloy cooled at different rates from $1020^{\circ} \mathrm{C}$ : (a) $4{ }^{\circ} \mathrm{C} / \mathrm{s},\left(\right.$ b) $1{ }^{\circ} \mathrm{C} / \mathrm{s},\left(\right.$ c) $0.4{ }^{\circ} \mathrm{C} / \mathrm{s},\left(\right.$ d) $0.1{ }^{\circ} \mathrm{C} / \mathrm{s}$.
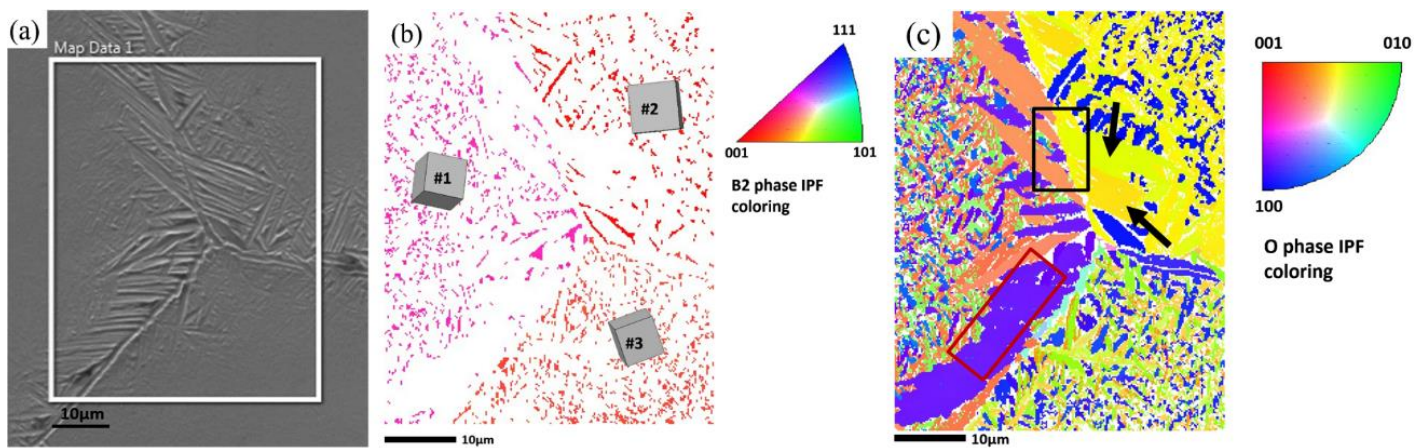

Figure 6. EBSD observations of Ti-22Al-25Nb alloy cooled at $0.1{ }^{\circ} \mathrm{C} / \mathrm{s}$ from $1100{ }^{\circ} \mathrm{C}$ (a) scanning area, (b) IPF of B2 phase, (c) IPF of O phase.

The EBSD analysis in the \#3 B2 grain and the pole figure of the B2 phase and O phase are shown in Figure 7. As a body-centered cubic unit, a single B2 phase unit cell contained six equivalent $\{110\}$ crystal planes. As an orthorhombic unit, an $\mathrm{O}$ phase unit cell contained only one equivalent (001) O plane and one equivalent [110] $\mathrm{O}$ direction due to the lattice parameters $\mathrm{a}=0.6089 \mathrm{~nm}, \mathrm{~b}=0.9569 \mathrm{~nm}$ and $\mathrm{c}=0.4666 \mathrm{~nm}$, respectively [35]. The positions of the six focusing points in the $\{001\} O$ pole figure (Figure $7 c$ ) are the same as those in the $\{110\} \mathrm{B} 2$ pole figure (Figure $7 \mathrm{~b}$ ), indicating that the $\mathrm{O}_{\mathrm{WI}}$ phase follows the plane relation (001)O/ / \{110\}B2 during a continuous cooling process. Zheng et al. [36] found that the lamellar O phase follows the plane relation $\{001\} \mathrm{O} / /\{110\} \mathrm{B} 2$, and all 12 variants of lamellar $\mathrm{O}$ phases appear during the second solution treatment. Even if there was no obvious visual orientation priority, the $\mathrm{O}_{\mathrm{WI}}$ phase still maintained the plane relation with the parent $\mathrm{B} 2$ phase. Therefore, this indicated that the precipitation probability of each $\mathrm{O}$ phase variant is approximately equal, and there was no obvious $\mathrm{O}$ phase variant selection effect in the \#3 B2 grain. 
(a)

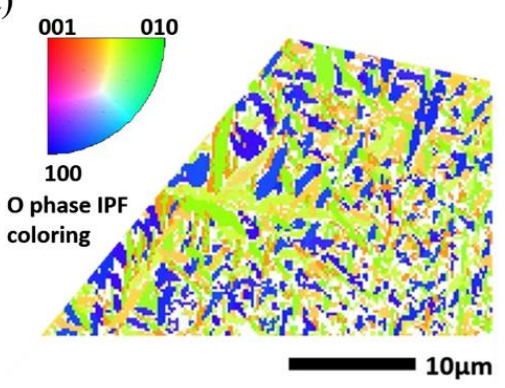

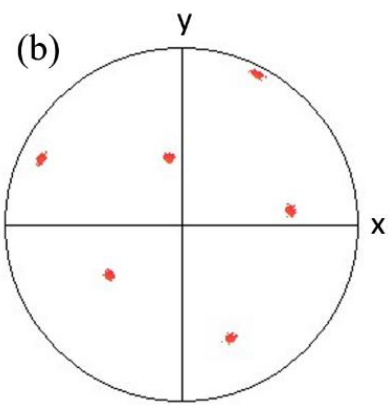

$\{110\}$ B2

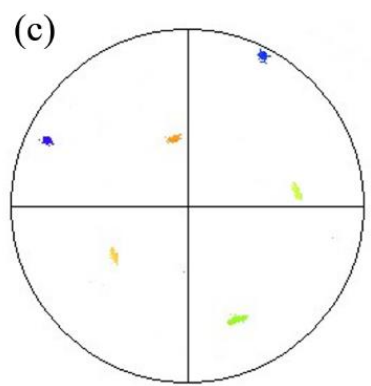

(001)O

Figure 7. (a) IPF map, (b) pole figures of $\{110\} B 2,(\mathbf{c})$ pole figures of $(001) \mathrm{O}$ in \#3 B2 grain.

As shown in Figure 8a, the purple lamellar O phase formed a cluster structure and grew into the \#1 B2 grain. The pole figures of the purple $\mathrm{O}_{\mathrm{WGB}}$ with the \#1 B2 pole figure are shown in Figure $8 \mathrm{~b}$. The $\{001\}$ plane of the purple $\mathrm{O}_{\mathrm{WGB}}$ is parallel to the $\{110\}$ plane of the \#1 B2 grain, and the $<110>$ direction of the $\mathrm{O}_{\mathrm{WGB}}$ is also parallel to the $<111>$ direction of the \#1 B2 grain. Thus, the $\mathrm{O}_{\mathrm{WGB}}$ maintained the specific orientation relationship, i.e., $(001) \mathrm{O} / /\{110\} \mathrm{B} 2$ and $<110>\mathrm{O} / /<111>\mathrm{B} 2$, with one of the two adjacent $\mathrm{B} 2$ grains. The grain boundary was decorated by $\mathrm{O}$ phases with different colors as shown in Figure $8 \mathrm{a}$ by the black arrows. This indicated that different crystallographic variants of the $\mathrm{O}$ phase precipitated simultaneously at one $\mathrm{B} 2$ grain boundary and formed the $\mathrm{O}_{\mathrm{GB}}$. It is known that the positions where the grain boundary and crystal defects gather are possible nucleation sites. Therefore, it can be inferred that there can be more than one nucleation site for the $\mathrm{O}$ phase on a single $\mathrm{B} 2$ grain boundary during the cooling process. The pole figures of the orange $\mathrm{O}_{\mathrm{GB}}$ and the cyan $\mathrm{O}_{\mathrm{GB}}$ with the \#1 $\mathrm{B} 2$ pole figure are shown in Figure $8 c, d$, respectively. Similar to the purple $\mathrm{O}_{\mathrm{WGB}}$, the orange $\mathrm{O}_{\mathrm{GB}}$ kept a specific orientation relationship with the \#1 $\mathrm{B} 2$ grain. As seen from Figure $8 \mathrm{~d}$, the cyan $\mathrm{O}_{\mathrm{GB}}$ did not have a specific orientation relationship because the $<110>$ direction of the cyan $\mathrm{O}_{\mathrm{GB}}$ is not strictly parallel to the $<111>$ direction of the \#1 B2 grain. However, the $\{001\}$ plane of the cyan $\mathrm{O}_{\mathrm{GB}}$ is parallel to the $\{110\}$ plane of the \#1 $\mathrm{B} 2$ grain. This indicated that the cyan $\mathrm{O}_{\mathrm{GB}}$ held a near-orientation relationship with the \#1 B2 grain based on this plane relation. It was pointed out that the products held a specific orientation relationship with the parents during the precipitation process, minimizing the interfacial energy [32] and nucleation activation energy [37]. A previous investigation [36] suggested that precipitates tried to maintain the orientation relationship with the parent phase grain as much as possible to reduce the nucleation activation energy when the $\mathrm{O}_{\mathrm{GB}}$ cannot maintain a specific orientation relationship with a certain $\mathrm{B} 2$ grain.

\subsubsection{O Phase Precipitation Mechanism from $\alpha_{2}$ Particles}

The EBSD analysis of the Ti-22Al-25Nb alloy cooled at $0.1^{\circ} \mathrm{C} / \mathrm{s}$ from $1020^{\circ} \mathrm{C}$ is shown in Figure 9. The green and pink rim $O$ phases appeared around the $\alpha_{2}$ particles when the cooling rate decreased to $0.1{ }^{\circ} \mathrm{C} / \mathrm{s}$ as marked by black arrows in Figure 9a. The $\{110\}$ and $<111>$ pole figures of the B2 phase are shown in Figure $9 \mathrm{~b}$. There are six focusing points on the $\{110\}$ B2 planes as shown in Figure 9b, indicated that all $\alpha_{2}$ particles and precipitated $\mathrm{O}$ phases are in one single $\mathrm{B} 2$ grain. Figures 10 and 11 show the crystallographic plane and crystallographic direction pole figures corresponding to the $\mathrm{B} 2$ phase and lamellar $\mathrm{O}$ phase and the $\alpha_{2}$ phase and precipitated rim $O$ phase, respectively. As seen from Figure 10, the $\{001\}$ and $<110>$ pole figures of the red lamellar $O$ phase coincide with the $\{110\}$ and $<111>$ pole figures of the B2 phase. Therefore, it can be concluded that in a single B2 grain, the lamellar O phase keeps the specific orientation relationship with the B2 phase. The $\{001\}$ plane of the green rim $O$ phase is parallel to the $\{0001\}$ plane of the purple $\alpha_{2}$ particle, and one $<110\rangle$ direction of rim $O$ is also parallel to one $<11 \overline{2} 0\rangle$ direction of the $\alpha_{2}$ particle, as shown in Figure 11. This suggests that the newly precipitated rim $O$ phase holds the specific orientation relationship with the parent $\alpha_{2}$ particles during the cooling process. 

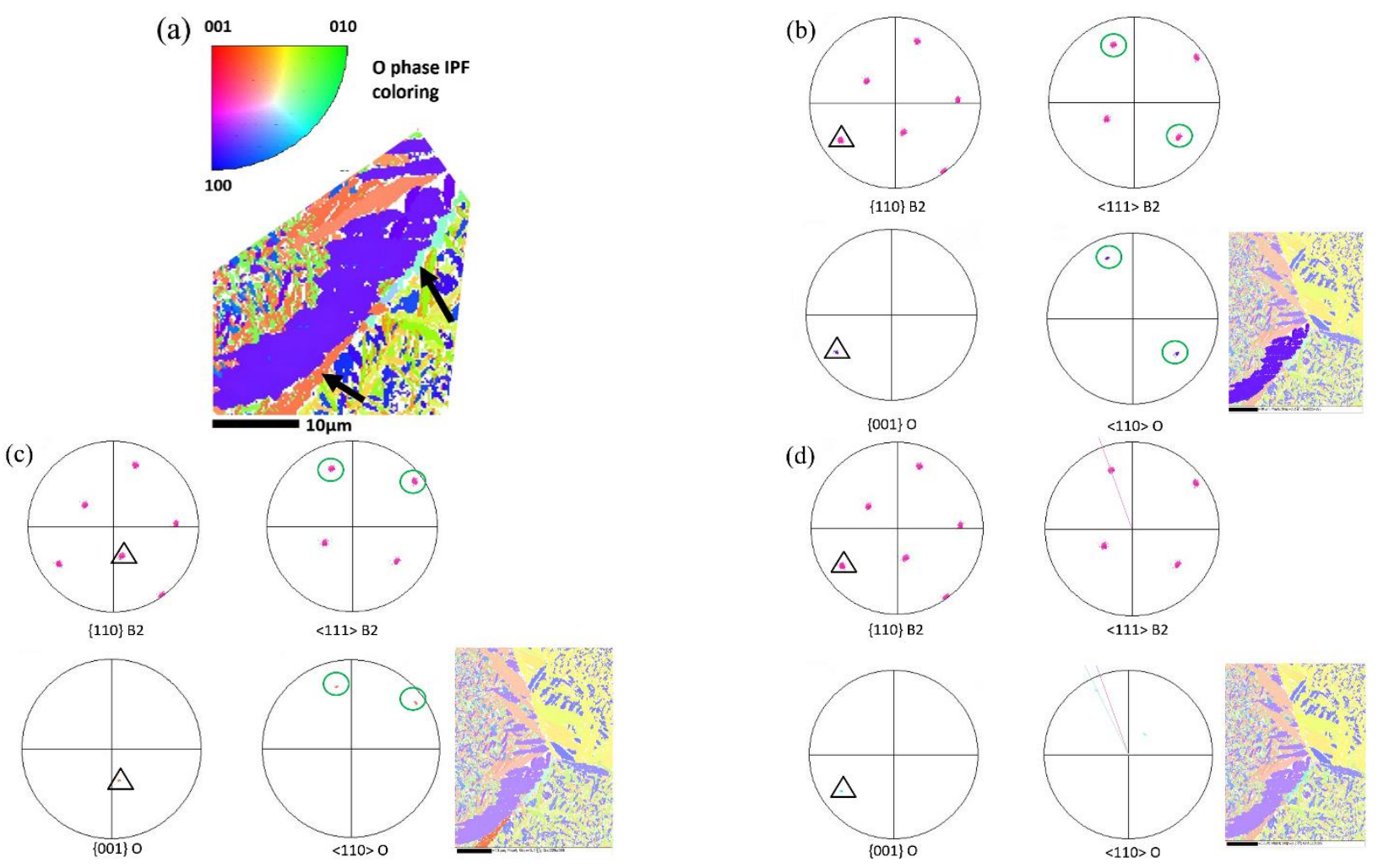

(d)
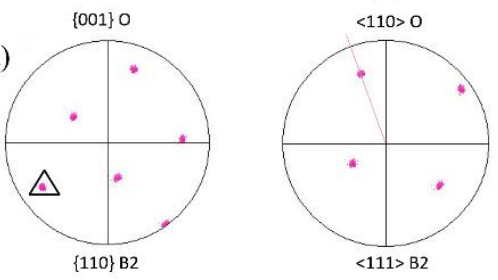

Figure 8. (a) partial view IPF map; $\{110\}$ and $<111>$ pole figures of the \#1 B2 phase corresponding to (b) $\{001\}$ and $<110>$ pole figures of the purple lamellar $O$ phase, (c) $\{001\}$ and $<110>$ pole figures of the orange $\mathrm{O}_{\mathrm{GB}}$, (d) $\{001\}$ and $<110>$ pole figures of the cyan $\mathrm{O}_{\mathrm{GB}}$.

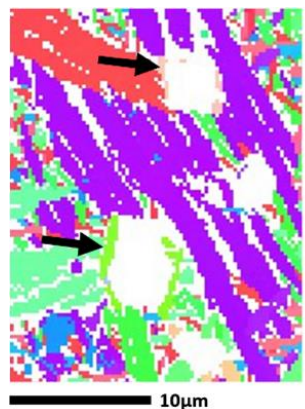

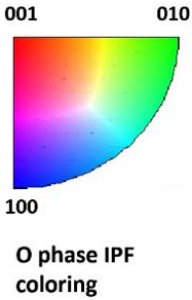

(a)

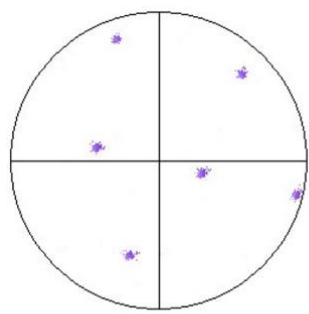

$\{110\}$ B2

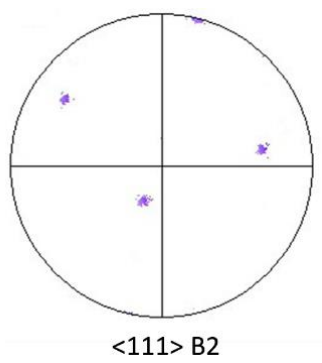

Figure 9. EBSD observation of Ti-22Al-25Nb alloy cooled at $0.1^{\circ} \mathrm{C} / \mathrm{s}$ from $1020^{\circ} \mathrm{C}$ (a) IPF map of $\mathrm{O}$ phase, (b) $\{110\}$ and $<111>$ pole figures of the B2 phase.

The diameter of the $\alpha_{2}$ and $\left(\mathrm{O}+\alpha_{2}\right)$ particles and the thicknesses of the lamellar $\mathrm{O}$ depicted in Figure 4 are all listed in Table 2. The diameter of the $\alpha_{2}$ particles without rim $\mathrm{O}\left(10{ }^{\circ} \mathrm{C} / \mathrm{s}\right.$ and $\left.4{ }^{\circ} \mathrm{C} / \mathrm{s}\right)$ is almost equal to those of $\left(\mathrm{O}+\alpha_{2}\right)$ particles $\left(1{ }^{\circ} \mathrm{C} / \mathrm{s}, 0.4{ }^{\circ} \mathrm{C} / \mathrm{s}\right.$ and $\left.0.1{ }^{\circ} \mathrm{C} / \mathrm{s}\right)$, indicating that the rim $\mathrm{O}$ phase formed through a decomposition reaction: $\alpha_{2} \rightarrow \alpha_{2}+\mathrm{O}$. Muraleedharan et al. $[15,21]$ found that the formation of the $\mathrm{O}$ phase precipitated on the periphery of the $\alpha_{2}$ particles is caused by the diffusional kinetics of the $\alpha_{2}$ phase. As a result of the $\mathrm{Nb}$ diffusion, the $\alpha_{2}$ phase contained supersaturation of niobium elements separated into two regions, one being the $\mathrm{Nb}$-rich region and the other the $\mathrm{Nb}$-lean region. $\mathrm{Nb}$-rich regions with composition closer to $\mathrm{Ti}_{2} \mathrm{AlNb}$ transformed to the $O$ phase $[16,38]$, which maintains a specific orientation relationship with the parent $\alpha_{2}$ particles, and $\mathrm{Nb}$-lean regions remained untransformed, that is, they retained the $\alpha_{2}$ phase. Wu et al. [39] considered that the $\mathrm{O}$ phase is a pseudohexagonal phase with a lattice distortion caused by a supersaturation of the $\alpha_{2}$ phase. In order to accommodate the excess $\mathrm{Nb}$, the crystalline cell of the hexagonal phase $\alpha_{2}$ had a slight distortion and transformed to 
O lattice [40], which means the $\alpha_{2}$ transformed to $\alpha_{2}$ (Nb-lean) and $\mathrm{O}$ (Nb-rich). Therefore, the rim $\mathrm{O}$ phase formed on the periphery of the $\alpha_{2}$ particles is controlled by a diffusion mechanism. It is difficult to form rim $\mathrm{O}$ in a short time due to the need for a large amount of $\mathrm{Nb}$ diffusion. Thus, no rim $\mathrm{O}$ phase appeared on the periphery of the $\alpha_{2}$ particles at high cooling rates during cooling from the $\left(\mathrm{B} 2+\alpha_{2}\right)$ region. The newly precipitated rim $\mathrm{O}$ phase provides fresh nucleation sites for other $\mathrm{O}$ phases. Thus, the precipitated rim $\mathrm{O}$ is conducive to the nucleation, growth and coarsening of the $\mathrm{O}$ lamellae around rim $\mathrm{O}$. According to the analysis above, the schematic of the formation process of the precipitated $\mathrm{O}$ phase with cooling from the $\mathrm{B} 2$ and $\left(\mathrm{B} 2+\alpha_{2}\right)$ region was shown in Figure 12. Figure 13 shows the comparison of microhardness versus cooling rate plots for the Ti-22Al-25Nb alloy. At cooling rates of $4{ }^{\circ} \mathrm{C} / \mathrm{s}$ and $10^{\circ} \mathrm{C} / \mathrm{s}$, the microhardness of the $\left(\alpha_{2}+\mathrm{B} 2\right)$ microstructure is larger than that of the B2 single phase. This is mainly because the fully B2 phase exhibits low strength, and equiaxed $\alpha_{2}$ particles have a strengthening effect. As the cooling rate decreases to $1{ }^{\circ} \mathrm{C} / \mathrm{s}$, either cooled from $1100{ }^{\circ} \mathrm{C}$ or $1020^{\circ} \mathrm{C}$, the microhardness of the alloy increases. From the previous analysis, a more needle-like $\mathrm{O}$ phase precipitates from the $\mathrm{B} 2$ matrix when the cooling rate is less than $4{ }^{\circ} \mathrm{C} / \mathrm{s}$. According to Ref. [11], the precipitated $\mathrm{O}$ phase is beneficial to the strength but detrimental to the plasticity of a $\mathrm{Ti}_{2} \mathrm{AlNb}$-based alloy. A similar phenomenon is also seen in Ref. [22]. Therefore, the increase in microhardness at lower cooling rates is due to the strengthening of the precipitated $O$ phase. In addition, the microhardness of the $(\mathrm{O}+\mathrm{B} 2)$ microstructure is larger than that of the $\left(\alpha_{2}+\mathrm{B} 2+\mathrm{O}\right)$ at a lower cooling rate. This is mainly because the $\alpha_{2}$ particles located on the grain boundary are detrimental to the mechanical properties of a $\mathrm{Ti}_{2} \mathrm{AlNb}$-based alloy, according to Ref. [2]. At a cooling rate of $0.1^{\circ} \mathrm{C} / \mathrm{s}$, there is a substantial decrease in microhardness either cooled from $1100{ }^{\circ} \mathrm{C}$ or $1020{ }^{\circ} \mathrm{C}$. According to EBSD analysis, the volume fraction of the $\mathrm{O}$ phase is $72.9 \%$ (cooled from $1100{ }^{\circ} \mathrm{C}$ ) and $61.8 \%$ (cooled from $1020^{\circ} \mathrm{C}$ ) when the cooling rate is decreased to $0.1^{\circ} \mathrm{C} / \mathrm{s}$. According to references [11,12,22], it is harmful to the strength of the alloy when the volume fraction of the precipitated $\mathrm{O}$ phase reaches a relatively large degree. In summary, the microstructure of the lamellar $\mathrm{O}+\mathrm{B} 2$ matrix has good microhardness and can be further examined as an ideal microstructure. The influence of the $\mathrm{O}$ phase lamellae size, the ratio of coarse lamellae to fine lamellae and the appropriate $\mathrm{O}$ phase volume fraction on the mechanical properties of a Ti-22Al-25Nb alloy will be further investigated in the future.

(a)

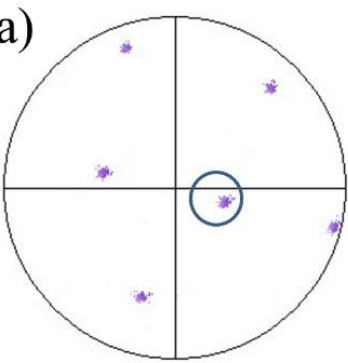

$\{110\}$ B2

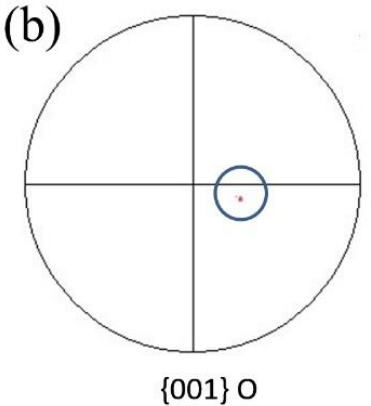

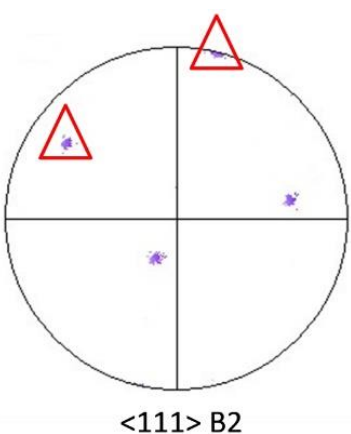

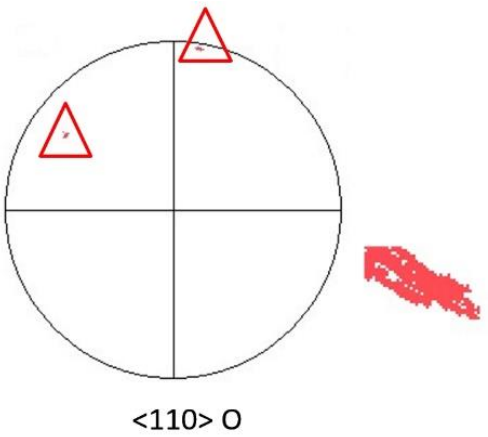

Figure 10. (a) $\{110\}$ and $<111>$ pole figures of the B2 phase, (b) $\{001\}$ and $<110>$ pole figures of the red lamellar $\mathrm{O}$ phase. 
(a)

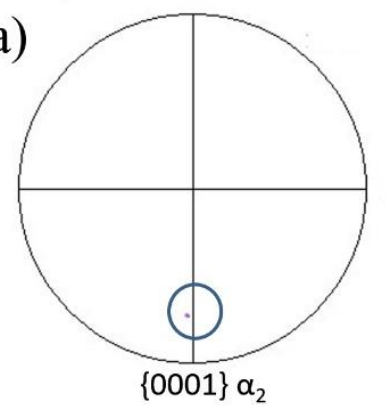

(b)

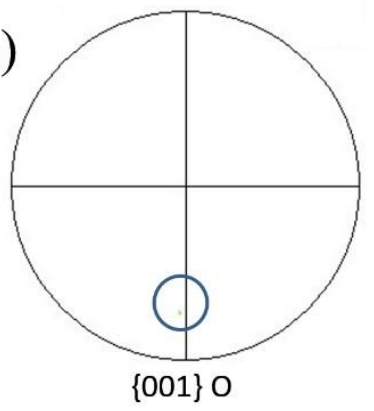

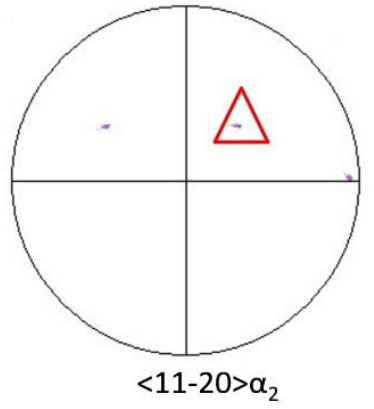

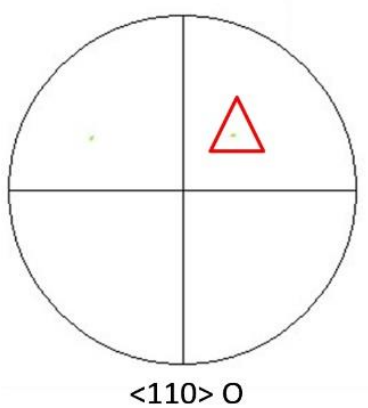

Figure 11. (a) $\{0001\}$ and $<11 \overline{2} 0>$ pole figures of the purple $\alpha_{2}$ phase, (b) $\{001\}$ and $<110>$ pole figures of the green rim $\mathrm{O}$ phase.

Table 2. $\mathrm{d}_{\alpha 2}(\mu \mathrm{m})$ under different cooling rates. $\mathrm{d}_{\alpha 2}$ is the diameter of the $\alpha_{2}$ particles, $\mathrm{r}_{\text {rim } \mathrm{O}}$ is the thickness of precipitated rim $\mathrm{O}$ and $\mathrm{d}_{\mathrm{m}}$ is the diameter of the $\left(\mathrm{O}+\alpha_{2}\right)$ particles.

\begin{tabular}{cccc}
\hline Cooling Rate $\left({ }^{\circ} \mathbf{C} / \mathbf{s}\right)$ & $\mathbf{d}_{\boldsymbol{\alpha} \mathbf{2}}$ & $\mathbf{r}_{\text {rim } \mathbf{~}}$ & $\mathbf{d}_{\mathbf{m}}$ \\
\hline 10 & 5.81 & 0 & 5.81 \\
4 & 5.79 & 0 & 5.79 \\
1 & 4.98 & 0.4 & 5.78 \\
0.4 & 4.36 & 0.7 & 5.76 \\
0.1 & 4.15 & 0.8 & 5.75 \\
\hline
\end{tabular}

(a)

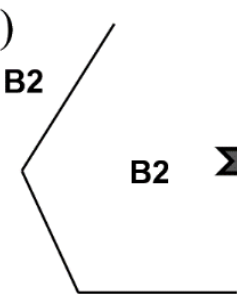

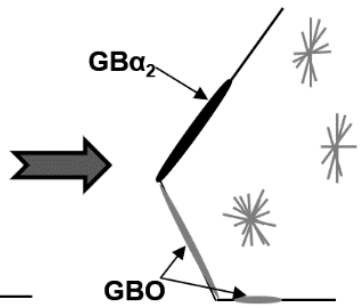
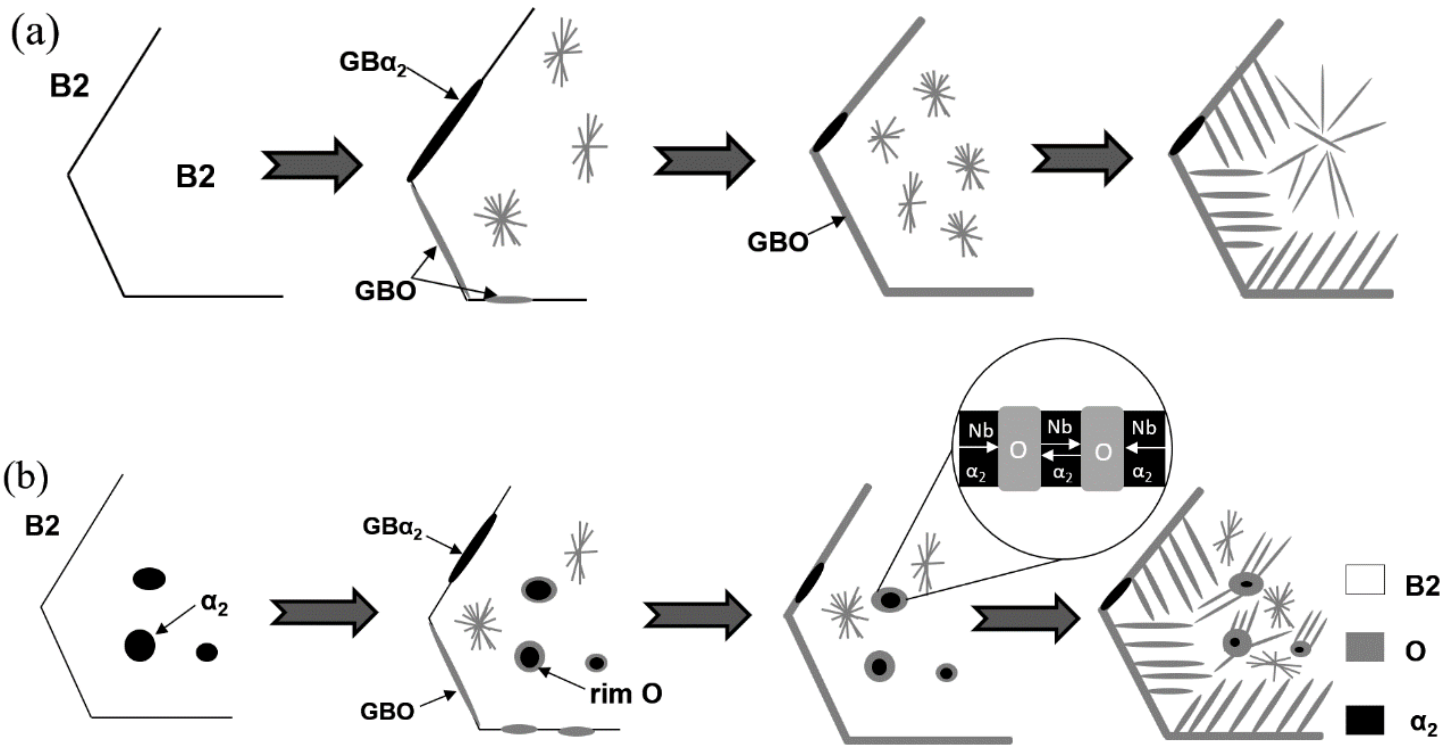

Figure 12. The schematic of the formation process of precipitated $\mathrm{O}$ phase with cooling from (a) B2 region, (b) B2 $+\alpha_{2}$ region. 


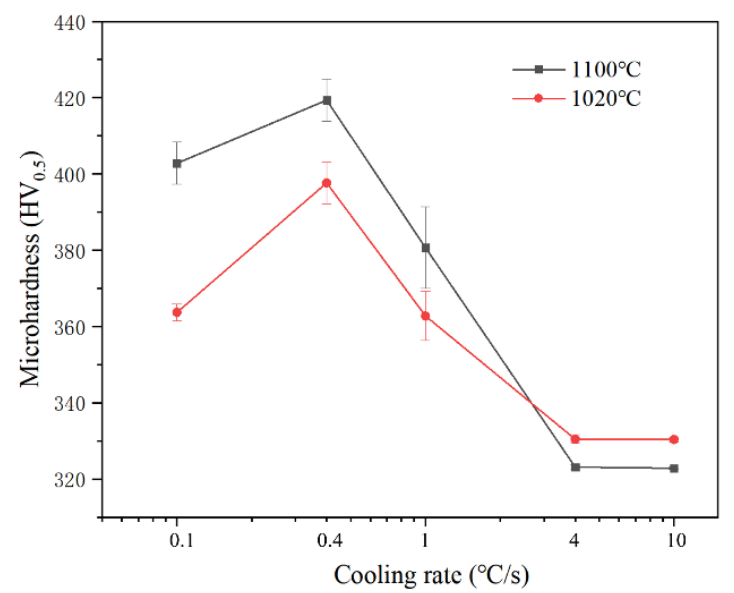

Figure 13. Microhardness versus cooling rate for Ti-22Al-25Nb alloy cooled from different regions.

\section{Conclusions}

In summary, the present research investigated the microstructural evolution of the $\mathrm{O}$ phase in a Ti-22Al-25Nb (at.\%) alloy during cooling at different cooling rates from different phase regions. It also summarized the precipitated formation mechanism of the $\mathrm{O}$ phase on B2 grain boundaries and within B2 grains and $\alpha_{2}$ grains. The main conclusions of this paper are as follows:

(1) Microstructure observation indicated that the cooling rates have a significant influence on the morphology of the precipitated $\mathrm{O}$ phase. As the cooling rate decreased, more floccular $\mathrm{O}$ phases precipitated directly from the B2 matrix, and the Widmanstätten grain boundary $\mathrm{O}$ precipitated along the grain boundary.

(2) When cooled from the (B2 $\left.+\alpha_{2}\right)$ region, the increase of the phase boundary provided favorable conditions for the nucleation of the $O$ phase due to the presence of $\alpha_{2}$ particles. The precipitated rim $\mathrm{O}$ phase appeared on the periphery of the $\alpha_{2}$ particles at lower cooling rates.

(3) The $\mathrm{O}_{\mathrm{WI}}$ phase maintained the plane relation with the parent $\mathrm{B} 2$ phase, and the $\mathrm{O}_{\text {WGB }}$ maintained the specific orientation relationship, i.e., $\{001\} \mathrm{O} / /\{110\} \mathrm{B} 2$ and $<110>\mathrm{O} / /<111>\mathrm{B} 2$, with one of the two adjacent $\mathrm{B} 2$ grains. The $\mathrm{O}_{\mathrm{GB}}$ keeps the specific orientation relationship with one of the $\mathrm{B} 2$ grains as much as possible. When it cannot maintain the specific orientation relationship with one of the $\mathrm{B} 2$ grains, the $\mathrm{O}_{\mathrm{GB}}$ maintains a near-orientation relationship with $\mathrm{B} 2$ grains on both sides to reduce the nucleation activation energy. There can be more than one nucleation site for the $\mathrm{O}$ phase on a single $\mathrm{B} 2$ grain boundary to form the $\mathrm{O}_{\mathrm{GB}}$.

(4) The rim $\mathrm{O}$ phase formed through a decomposition reaction of $\alpha_{2} \rightarrow \alpha_{2}$ (Nb-lean) $+\mathrm{O}$ (Nb-rich) is controlled by a diffusional mechanism and maintains specific orientation relationship, i.e., $\{001\} \mathrm{O} / /\{0001\} \alpha_{2}$ and $<110>0 / /<11-20>\alpha_{2}$, with the parent $\alpha_{2}$ particles.

Author Contributions: Conceptualization, D.L.; formal analysis, F.Z.; methodology, J.X.; project administration, W.Z.; investigation, D.L.; writing—original draft preparation, D.L.; resources, X.M.; supervision, X.L. All authors have read and agreed to the published version of the manuscript.

Funding: This work is financially supported by the Program of National Key Research and Development Plan of China (2016YFB0301203), the Natural Science Foundation of Shaanxi province of China (2020JQ-156) and the Fundamental Research Funds for the Central Universities (3102019TS0404).

Data Availability Statement: The data are not publicly available due to the fact that these data are part of an ongoing study.

Acknowledgments: We would like to thank the Analytical \& Testing Center of Northwestern Polytechnical University for the convenience of the experimental tests. 
Conflicts of Interest: The authors declare no conflict of interest.

\section{References}

1. Banerjee:, D.; Gogia, A.; Nandy, T.; Joshi, V. A new ordered orthorhombic phase in a Ti 3 Al-Nb alloy. Acta. Metall. 1988, 36, 871-882. [CrossRef]

2. Kumpfert, J. Intermetallic alloys based on orthorhombic titanium aluminide. Adv. Eng. Mater. 2001, 3, 851-864. [CrossRef]

3. Boehlert, C.; Cowen, C.; Jaeger, C.; Niinomi, M.; Akahori, T. Tensile and fatigue evaluation of Ti-15Al-33Nb (at.\%) and Ti-21Al$29 \mathrm{Nb}$ (at.\%) alloys for biomedical applications. Mater. Sci. Eng. C 2005, 25, 263-275. [CrossRef]

4. Nandy, T.; Banerjee, D. Creep of the orthorhombic phase base on the intermetallic Ti 2 AlNb. Intermetallics 2000, 8, 915-928. [CrossRef]

5. Wang, W.; Zeng, W.; Xue, C.; Liang, X.; Zhang, J. Microstructural evolution, creep, and tensile behavior of a Ti-22Al-25Nb (at \%) orthorhombic alloy. Mater. Sci. Eng. A 2014, 603, 176-184. [CrossRef]

6. Wang, W.; Zeng, W.; Liu, Y.; Xie, G.; Liang, X. Microstructural evolution and mechanical properties of Ti-22Al-25Nb (at.\%) orthorhombic alloy with three typical microstructures. J. Mater. Eng. Perform. 2018, 27, 293-303. [CrossRef]

7. Wang, W.; Zeng, W.; Xue, C.; Liang, X.; Zhang, J. Quantitative analysis of the effect of heat treatment on microstructural evolution and microhardness of an isothermally forged Ti-22Al-25Nb (at.\%) orthorhombic alloy. Intermetallics 2014, 45, 29-37. [CrossRef]

8. Zheng, Y.; Zeng, W.; Li, D.; Zhao, Q.; Liang, X.; Zhang, J.; Ma, X. Fracture toughness of the bimodal size lamellar O phase microstructures in Ti-22Al-25Nb (at.\%) orthorhombic alloy. J. Alloys Compd. 2017, 709, 511-518. [CrossRef]

9. Germann, L.; Banerjee, D.; Guédou, J.; Strudel, J. Effect of composition on the mechanical properties of newly developed $\mathrm{Ti}_{2} \mathrm{AlNb}$-based titanium aluminide. Intermetallics 2005, 13, 920-924. [CrossRef]

10. Boehlert, C.; Majumdar, B.; Seetharaman, V.; Miracle, D. Part I. The microstructural evolution in Ti-Al-Nb O + Bcc orthorhombic alloys. Metall. Mater. Trans. A 1999, 30, 2305-2323. [CrossRef]

11. Boehlert, C. Part III. The tensile behavior of Ti-Al-Nb O + Bcc orthorhombic alloys. Metal. Mater. Tran. A 2001, 32, 1977-1988. [CrossRef]

12. Zheng, Y.; Zeng, W.; Zhang, P. Anti-correlation between solution strengthening and precipitation strengthening in lamellar O microstructures of a Ti2AlNb based alloy. J. Alloys Compd. 2020, 847, 156470. [CrossRef]

13. Wang, W.; Zeng, W.; Xue, C.; Liang, X.; Zhang, J. Designed bimodal size lamellar O microstructures in $\mathrm{Ti}_{2} \mathrm{AlNb}$ based alloy: Microstructural evolution, tensile and creep properties. Mater. Sci. Eng. A 2014, 618, 288-294.

14. Wang, W.; Zeng, W.; Xue, C.; Liang, X.; Zhang, J. Microstructure control and mechanical properties from isothermal forging and heat treatment of Ti-22Al-25Nb (at.\%) orthorhombic alloy. Intermetallics 2015, 56, 79-86. [CrossRef]

15. Muraleedharan, K.; Banerjee, D.; Banerjee, S.; Lele, S. The $\alpha 2$-to-O transformation in Ti-Al-Nb alloys. Phil. Mag. A 1995, 71, 1011-1036. [CrossRef]

16. Wu, Y.; Yang, D.; Song, G. The formation mechanism of the O phase in a Ti3Al-Nb alloy. Intermetallics 2000, 8, 629-632. [CrossRef]

17. Wang, W.; Zeng, W.; Li, D.; Zhu, B.; Zheng, Y.; Liang, X. Microstructural evolution and tensile behavior of Ti $2 \mathrm{AlNb}$ alloys based $\alpha_{2}$-phase decomposition. Mater. Sci. Eng. A 2016, 662, 120-128. [CrossRef]

18. Sadi, F.; Servant, C. On the B2 $\rightarrow$ O phase transformation in Ti-Al-Nb alloys. Mater. Sci. Eng. A 2003, 346, 19-28. [CrossRef]

19. Bendersky, L.; Roytburd, A.; Boettinger, W. Phase transformations in the (Ti, $\mathrm{Al})_{3} \mathrm{Nb}$ section of the Ti-Al-Nb system-I. Microstructural predictions based on a subgroup relation between phases. Acta Metall. Mater. 1994, 42, 2323-2335.

20. Bendersky, L.; Boettinger, W. Phase transformations in the (Ti, Nb) ${ }_{3} \mathrm{Al}$ section of the Ti-Al-Nb system-II. Experimental TEM study of microstructures. Acta Metall. Mater. 1994, 42, 2337-2352. [CrossRef]

21. Muraleedharan, K.; Gogia, A.; Nandy, T.; Banerjee, D.; Lele, S. Transformations in a Ti-24Al-15Nb alloy: Part I. Phase equilibria and microstructure. Metall. Trans. 1992, 23, 401-415. [CrossRef]

22. Wei, B.; Tang, B.; Chen, X.; Xu, Q.; Zhang, S.; Kou, H.; Li, J. Precipitation behavior of orthorhombic phase in Ti-22Al-25Nb alloy during slow cooling aging treatment and its effect on tensile properties. Metals 2020, 10, 1515. [CrossRef]

23. Muraleedharan, K.; Nandy, T.; Banerjee, D.; Lele, S. Phase stability and ordering behaviour of the O phase in Ti-Al-Nb alloys. Intermetallics 1995, 3, 187-199. [CrossRef]

24. Huang, Y.; Liu, Y.; Li, C.; Ma, Z.; Yu, L.; Li, H. Microstructure evolution and phase transformations in Ti-22Al-25Nb alloys tailored by super-transus solution treatment. Vacuum 2019, 161, 209-219. [CrossRef]

25. Hagiwara, M.; Emura, S.; Araoka, A.; Kong, B.; Tang, F. Enhanced Mechanical Properties of Orthorhombic Ti ${ }_{2} \mathrm{AlNb}-\mathrm{Based}$ Intermetallic Alloy. Met. Mater. Int. 2003, 9, 265-272. [CrossRef]

26. Raghavan, V. Al-Nb-Ti (Aluminum-Niobium-Titanium). J. Phase. Equilib. Diff. 2005, 26, 360-368. [CrossRef]

27. Gogia, A.; Nandy, T.; Muraleedharan, K.; Banerjee, D. The effect of heat treatment and niobium content on the room temperature tensile properties and microstructure of $\mathrm{Ti}_{3} \mathrm{Al}-\mathrm{Nb}$ alloys. Mater. Sci. Eng. A 1992, 159, 73-86. [CrossRef]

28. Kumpfert, J.; Kaysser, W. Orthorhombic titanium aluminides: Phases, phase transformation and microstructure evolution. Int. J. Mater. Res. 2001, 92, 128-134.

29. Popov, A.; Illarionov, A.; Grib, S.; Demakov, S.; Karabanalov, M.; Elkina, O. Phase and structural transformations in the alloy on the basis of the orthorhombic titanium aluminide. Phys. Met. Metallogr+. 2008, 106, 399-410. [CrossRef]

30. Kazantseva, N.; Lepikhin, S. Study of the Ti-Al-Nb phase diagram. Phys. Met. Metallogr+. 2006, 102, 169-180. [CrossRef]

31. Sun, Z.; Li, X.; Wu, H.; Yang, H. A unified growth model of the secondary grain boundary a phase in TA15 Ti-alloy. J. Alloys Compd. 2016, 689, 693-701. [CrossRef] 
32. Shi, R.; Dixit, V.; Fraser, H.; Wang, Y. Variant selection of grain boundary a by special prior b grain boundaries in titanium alloys. Acta Mater. 2014, 75, 156-166. [CrossRef]

33. Li, D.; Boehlert, C. Processing Effects on the grain-boundary character distribution of the orthorhombic phase in Ti-Al-Nb alloys. Metall. Mater. Trans. 2005, 36, 2569-2584. [CrossRef]

34. Xue, C.; Zeng, W.; Xu, B.; Liang, X.; Zhang, J.; Li, S. B2 grain growth and particle pinning effect of Ti-22Al-25Nb orthorhombic intermetallic alloy during heating process. Intermetallics 2012, 29, 41-47. [CrossRef]

35. Rackel, M.; Stark, A.; Gabrisch, H.; Schell, N.; Schreyer, A.; Pyczak, F. Orthorhombic phase formation in a Nb-rich $\gamma$-TiAl based alloy-An in situ synchrotron radiation investigation. Acta Mater. 2016, 121, 343-351. [CrossRef]

36. Zheng, Y.; Zeng, W.; Li, D.; Xu, J.; Ma, X.; Liang, X.; Zhang, J. Orthorhombic precipitate variant selection in a Ti $2 \mathrm{AlNb} \mathrm{based}$ alloy. Mater. Design 2018, 158, 46-61. [CrossRef]

37. Furuhara, T.; Maki, T. Variant selection in heterogeneous nucleation on defects in diffusional phase transformation and precipitation. Mater. Sci. Eng. A 2001, 312, 145-154. [CrossRef]

38. Semiatin, S.; Smith, P. Microstructural evolution during rolling of Ti-22Al-23Nb sheet. Mater. Sci. Eng. A 1995, 202, 26-35. [CrossRef]

39. Wu, Y.; Zhen, L.; Yang, D.; Mao, J. TEM observation of the $\alpha_{2} / \mathrm{O}$ interface in a Ti 3 A1-Nb alloy. Mater. Lett. 1997, 32, 319-323. [CrossRef]

40. Banerjee, D. Deformation of the $\mathrm{O}$ and $\alpha_{2}$ phases in the Ti-Al-Nb system. Phil. Mag. A 1995, 72, 1559-1587. [CrossRef] 